СМИРНОВ Сергей Викторович,

д-р ист. наук, профессор кафедры новой и новейшей истории Уральского федерального университета (г. Екатеринбург).

Электронная почта: s.v.smirnov@urfu.ru

\title{
Русские курорты в Корее в конце 1920-х - начале 1940-х гг. (на примере деятельности семьи Янковских)
}

\section{УДК $325.2+929.52$}

русская эмиграция,

Янковские,

Корея,

Новина,

Лукоморье,

курортное хозяйство, фронтир,

самодеятельный театр
DOI https://doi.org/10.24866/2542-1611/2021-3/74-84

В статье рассматривается уникальный пример успешного развития крупного русского курортного хозяйства в Корее в условиях эмиграции. Главными причинами успешности Янковских, как показывают источники личного происхождения, являлись семейно-клановый характер организации хозяйства, фронтирное сознание представителей семьи, облегчавшее процесс социальной адаптации, и достаточно устойчивый социально-экономический контекст, обеспеченный политикой японских властей Кореи. В 1930-е гг. курорты Янковских являлись важным явлением культурной жизни дальневосточной русской эмиграции.

Работа выполнена при поддержке гранта РФФИ № 19-59-51004 «Роль диаспоральных сообществ в социально-экономическом и культурном развитии России и Кореи в XX в. (на материалах сообществ русских эмигрантов в Корее и корейской общины Урала)».

1 Только при изучении военной и политической деятельности русской эмиграции в Китае в 1920-1945 гг. нами было выявлено около двухсот публикаций отечественных авторов.

Для иитирования:

Смирнов С. В. Русские курорты в Корее в конце 1920-х - начале 1940-х гг. (на примере деятельности семьи Янковских) // Известия Восточного института. 2021 № 3. C. 74-84. DOI https://doi.org/10.24866/25421611/2021-3/74-84
Богатейшая историография русской эмиграции 1920-х 1940-х гг. в странах Дальнего Востока (особенно в Китае) ${ }^{1}$ отнюдь не изобилует работами, посвященными повседневной жизни эмигрантов [7; 9]. Но даже в трудах, так или иначе касающихся эмигрантской повседневности, проблема санаторно-курортного отдыха эмигрантов остается практически неизученной $[10 ; 11]$. Между тем существовали яркие примеры организации и успешного развития курортного дела представителями эмиграции. В частности, это касается деятельности семьи Янковских в Корее.

Среди фамилий немногочисленных русских эмигрантов, нашедших себе пристанище в Корее, фамилия Янковских как в эмигрантский период, так и сегодня является самой известной. Деятельность членов семьи неоднократно становилась объектом исследовательского интереса, в том числе и ведение ими обширного хозяйства в Новине, однако предпринимательская активность Янковских в курортной сфере не получила самостоятельного освещения $[5 ; 8 ; 14 ; 16]$. Цель настоящей статьи - показать на примере деятельности семьи Янковских в Корее участие русских эмигрантов в развитии курортного бизнеса Восточной Азии в контексте формирования новых структур повседневности в условиях чужого социально-культурного контекста. Данная проблема связана с более широкой и крайне актуальной сегодня, в эпоху массового миграционного движения, проблемой социальной адаптации эмигрантов к условиям новой среды проживания. Изучение структур повседневности обусловило обращение к источникам личного происхождения, в которых, следуя за авторами теории социального конструирования реальности П. Бергером и Т. Лукманом, и отражается та «реальность, которая интерпретируется людьми и имеет для них субъективную значимость в качестве целого жизненного мира» [2, с. 38]. В данном случае 
мы привлекли в качестве источников воспоминания, дневники, биографические повествования, вышедшие из-под пера как самих представителей семьи Янковских, так и людей, которые их хорошо знали $[1 ; 4 ; 6 ; 12 ; 13]$.

\section{Янковские - основатели русского курортного бизнеса в Корее}

В дореволюционный период слава семьи Янковских, основоположником которой являлся ссыльный польский шляхтич, участник восстания 1863 г. Михаил Иванович Янковский, гремела по всему Дальнему Востоку. Янковские имели крупное хозяйство в бухте Сидеми (современный полуостров Яновского в Амурском заливе), специализируясь на коневодстве, пантовом оленеводстве, лесоводстве, промышленном выращивании женьшеня и промысловой охоте. Кроме того, глава семьи сделал серьезный вклад в развитие географии, энтомологии, орнитологии и археологии края. Возглавивший семейный бизнес в Сидеми в 1906 г. второй сын Михаила Ивановича - Юрий не принял власти большевиков и в сентябре 1922 г. перевёз большую часть членов семейства, близких родственников и своих служащих (всего около 70 человек), а также часть движимого имущества в Корею. Первоначально Янковские поселились в недавно возникшем портовом городе Сейсин (современный Чхонджин) на восточном побережье северной части Кореи. В первые годы эмиграции семья предприняла ряд не очень удачных попыток организовать собственное дело. Удерживаться на плаву позволяла промысловая охота и организация охотничьего сафари для богатых иностранцев.

В 1925 г. Юрий Михайлович обнаружил в пятидесяти километрах к югу от Сейсина в долине небольшой горной реки Омпо (Онпхо) место для основания нового хозяйства. Долина реки Омпо была богата термальными источниками (их вода имела большое содержание серных компонентов), позволившими японцам создать здесь целую сеть гостиниц, предоставлявших водолечебные процедуры [13, с. 361]. Девственный, преимущественно сосновый лес, покрывавший местные очень живописные горы, изобиловал промысловой дичью, в том числе здесь обитали нагонявшие страх на местных жителей тигры. Межгорные распадки давали достаточно корма для разведения крупного скота. Немаловажным было и то, что богатейшая природа этих мест открывала хорошие возможности для научных изысканий, прежде всего в области энтомологии. Итак, почти всё, чем занималась семья Янковских в Сидеми, могло быть воспроизведено в Омпо.

Загоревшись новыми перспективами, Юрий Михайлович сначала арендовал, а вскоре выкупил обширный земельный участок в двенадцати километрах от железнодорожной станции Шюоцу (кор. Чуыль). Японские власти Кореи давали иностранцам, в том числе и русским эмигрантам, право приобретать землю на корейской территории. Крупный заём на приобретение земли Янковский получил в одном из харбинских банков благодаря поручительству Бориса Юльевича Бринера, своего родственника по линии жены, швейцарского подданного и успешного советского предпринимателя и промышленника [13, с. 322]. В свое время Бринеры были частыми гостями в Сидеми и после эмиграции Янковских сохраняли с ними связь. В начале 1930-х гг. в связи с угрозой потери всего имущества в СССР всё семейство Бринеров (три брата, старший из которых - Леонид уже с 1920-х гг. жил преимущественно в Харбине) перебралось в Китай [3, с. 119122]. 
На приобретённой земле Янковскими было построено семейное поместье, получившее название Новина в честь родового герба (Nowina, Woinia). В начале 1930-х гг. Юрий Михайлович, заметно укрепивший к этому времени финансовое положение семьи, приобрёл еще один большой участок земли в восемнадцати километрах от Новины на побережье Японского моря, славившийся своими многокилометровыми песчаными пляжами. Новое владение получило наименование Лукоморье.

В 1930-е гг. хозяйство Янковских приобрело комплексный характер, основные статьи дохода обеспечивали пантовое оленеводство, промысловая охота и курортный бизнес. В условиях эмиграции, когда у предпринимателя отсутствовал устойчивый правовой статус (отсутствие гражданства), государственная поддержка и национальный социально-культурный контекст, успешное функционирование такого хозяйства могло быть обеспечено только концентрацией всех наличествующих ресурсов. С этим Юрий Михайлович, имея безусловную поддержку своей жены Маргариты Михайловны, хорошо справился. Человек энергичный, крайне работоспособный и волевой - «двужильный», как писал о нём его старший сын Валерий, Юрий Михайлович сохранил костяк сидемийского клана Янковских. Из пяти родных детей Юрия Михайловича и Маргариты Михайловны (две дочери 1907 и 1909 годов рождения, и три сына 1911, 1914 и 1920 годов рождения) только старшая дочь Муза (Ливия) покинула семью и уехала жить в Шанхай. Однако, живя с семьей в Шанхае, Муза никогда не порывала связей с Кореей. Остальные дети, получив в основном домашнее образование, были рано вовлечены в обеспечение семейного хозяйства. Все они являлись великолепными охотниками и наездниками, имея в арсенале и ряд других специальностей - строитель, шофер-механик, оленевод, инструктор по туризму. Помимо семьи Юрия Михайловича клан Янковских в Новине включал в себя старшего брата Юрия Михайловича - Александра, семью его младшего брата - Павла (до 1928 г.), племянника - Василия Пауэрса, ряд старых сотрудников ещё со времен Сидеми - няню японку Осада, семейство православных корейцев Магай, чету Козак, и ряд новых служащих - В.Н. Валькова, Ф.П. Соломахина и др.

Другим важным ресурсом семьи являлся капитал связей - родственные и дружественные связи в среде предпринимателей русского Китая, а также хорошие отношения с японскими провинциальными властями, которым Янковские оказывали некоторые «полудобровольные» услуги. Мужчины семьи входили в состав местной самообороны, участвовали в сборе сведений о Советском Союзе путем прослушивания советских широковещательных радиостанций [13, c. 360,419$]$. Кроме того, Янковские сумели вывезти в Корею некоторые финансовые средства и часть своего имущества, которая в дальнейшем была продана и обращена в стартовый капитал для реализации коммерческих проектов, а также большой арсенал оружия и боеприпасов.

Организация курортной инфраструктуры заняла у Янковских несколько лет. Часть приобретенной земли в Новине и Лукоморье была выделена для продажи и устройства дач. Стандартный дачный участок составлял 300 цубо (около 1 тыс. квадратных метров) [13, c. 322]. Первую рекламную акцию по продаже земли под дачи Юрий 
Михайлович организовал самостоятельно в Харбине и Тяньцзине в 1927 г., попросту обходя с этим предложением своих родственников и знакомых [4, с. 421]. В дальнейшем объявления о продаже земельных участков давались через эмигрантские газеты.

На предложение Янковских откликнулись прежде всего некоторые состоятельные харбинцы. Для них, живших далеко от морского побережья, важную роль сыграло и открытие в 1933 г. железнодорожной ветки Чанчунь (Синьцзин) - Сейсин. Добраться от Харбина до станции Шюоцу теперь можно было менее, чем за 24 часа [4, с. 422]. Построенная несколькими годами ранее, в 1928-м г., линия Гензан (Вонсан) - Сейсин связала порт с общекорейской железнодорожной сетью и обеспечила доступ русским, проживавшим в Сеуле, к курортам. Впрочем, состоятельных эмигрантов среди малочисленной сеульской колонии (около 200 человек) было немного. Известно только, что Новину и Лукоморье посещали члены семьи бывшего российского дипломата С.В. Чиркина [13, с. 323, 324]. Заинтересовались корейскими владениями Янковских и некоторые русские шанхайцы, для которых главным курортом являлся Циндао, находившийся гораздо ближе к Шанхаю и имевший более тёплый климат. Но в случае Лукоморья подкупала почти дикая природа Кореи и корейская дешевизна, цены в Циндао были гораздо выше.

Контингент дачников Янковских состоял в массе своей из родственников, друзей, знакомых семьи, знакомых друзей и т. п. Завсегдатаями курортов являлись члены клана Янковских, проживавшие в Шанхае, - семьи Музы Юрьевны и Павла Михайловича, Шевелёвых, родственников по женской линии, и Пауэрсов. Свои дачи в Новине и Лукоморье имели братья Бринеры - Леонид и Борис. Из близких друзей - Гинце, Эллерсы, Варгасовы, Васильевы и др. Из других владельцев дач известны Е.С. Кауфман, издатель журнала «Рубеж» и технический директор издательства «Заря», Г.Н. Шипков, главный редактор «Зари», К.Ф. Кореневский, управляющий Мулинскими угольными копями, доктор М.В. Чердынцев из Тяньцзина, Унтербергеры, Юзефовичи и др. [4, с. $432 ; 12$, с. 157,$230 ; 13$, с. 358$]$.

Помимо владельцев дач в Новине отдыхали те, кто снимал комнату на весь курортный сезон или какую-то его часть в одном из домов, принадлежавших Янковским. По воспоминаниям Валерия Юрьевича, в разгар летнего сезона в Новине располагалось до 50-60 гостей и еще некоторое количество дачников в Лукоморье. Под размещение отдыхающих отдавался весь жилой фонд - два четырехкомнатных домика позади театра, бывшая контора, домик Музы Янковской, дом под названием «Гусарский Монастырь», а с 1935 г. - большая фанза «Турек» (зимняя база), располагавшаяся на площади перед театром [4, с. 428].

Были гостями Янковских и некоторые иностранцы - японцы, в том числе генерал-губернатор Кореи генерал Коисо Куниаки и другие высокие чины [13, с. 355], и европейцы. По мнению Д. Кларка, для европейцев, базировавшихся в основном на курортах Вонсана и Инчхона, Новина и Лукоморье не имели большой привлекательности отчасти из-за того, что Янковские и их сотрудники не говорили на английском языке [14, p. 48].

Русские курорты в Корее достигли своего расцвета в середине 1930-х гг., когда число отдыхавших в разгар сезона могло доходить до сотни человек. Главным неблагоприятным фактором для ведения 
2 ГААОСО - Государственный архив административных органов Свердловской области. курортного бизнеса стал фактор внешний - углубление вооруженного противостояния между Японией и Китаем после 1937 г. и рост советско-японских противоречий. По воспоминаниям М.М. Гинце, курортный сезон 1941 г. был неожиданно прерван в июле эвакуацией с возвращением на места постоянного проживания всех русских отдыхающих без объяснения каких-либо причин со стороны японских властей [4, с. 440]. Окончательное закрытие курортов положило начало Тихоокеанской войны. К этому времени относится и распад большой семьи Янковских. Виктория с мужем уехала в Маньчжоу-го еще в 1939 г., бывая в Корее только наездами, а после вторичной женитьбы отца (Маргарита Михайловна скончалась в 1936 г.) в 1941 г. в Маньчжурию перебрался и Валерий, где организовал собственное хозяйство - «Тигровый хутор». Последний ограниченный курортный сезон в Новине и Лукоморье пришёлся на лето 1942 г.

\section{Организация курортной жизни в Новине и Лукоморье}

Дачный поселок Новины начал складываться не ранее 1928 г. Одной из наиболее ранних построек стала дача близких друзей Янковских четы Гинце (Михаил Александрович, управляющий фанерного завода в Харбине, и Наталья Борисовна), впервые принявшая своих хозяев летом 1929 г. На протяжении всех тридцатых годов Гинце (главным образом Наталья Борисовна и три её сына) были постоянными гостями курортов, обычно проводя в Корее целое лето [3, с. 422].

Первые дома для дачников строили сами Юрий Михайлович и два его старших сына - Валерий и Арсений. Домики были типовыми - «открытая веранда, с нее вход в большую комнату во всю ширь дома, а из этой комнаты вход в две раздельные, поменьше, наполовину большой комнаты. И вход в кладовку и кухню из большой комнаты» [4, с. 422]. К кухне примыкала ванная комната с умывальником и ванной, которые наполнялись доставляемой ведрами водой из реки. Наряду с водопроводом в Новине отсутствовали канализация и электричество $[4$, c. $422 ; 6$, с. 68$]$. Позднее к строительству стали привлекать наёмных рабочих. Состоятельные дачники осуществляли строительство по индивидуальным планам, как, например, Е.С. Кауфман, чьи просторная дача и участок земли были огорожены металлической сеткой [13, с. 240]. К слову сказать, стоимость участка и дома Кауфмана в Новине оценивалась в 1943 г. примерно в 6 тыс. гоби [денежная единица Маньчжоу-го, приравненная к японской иене - С.С.] (ГААОСО. Ф. Р-1. Оп. 2. Д. 41665. Наблюдательное дело. Л. 18).

Центральной постройкой Новины являлся дом самих Янковских «Катамаран», имевший Т-образную форму и построенный из лиственничных досок на фундаменте из речных валунов. Свои дома имели Павел Михайлович и Муза Юрьевна. Большая столовая вмещала до 40 человек, здесь обедали и сами хозяева, и отдыхающие [6, с. 69; 13, c. 322]. Отдельно располагалось здание клуба-театра, служившее основным местом организации культурно-развлекательных мероприятий. Во время сильного наводнения 1938 г. «Катамаран» и ряд других зданий Новины были полностью разрушены, но уже в течение следующего года Янковские восстановили все свои потери. Новые здания строились более основательно и вне зоны затопления. Наряду с жилыми постройками было возведено высокое здание театра, имевшее свой балкон. В нем разместилась большая столовая со сценой, 
соединявшаяся галереей с просторной кухней. В зале столовой были выставлены призовые кубки, выигранные скакунами Янковских, и многочисленные охотничьи трофеи - черепа и рога добытых зверей. Позади здания театра располагалась контора [13, с. 369].

Снабжение всех курортников продуктами и всем необходимым Янковские взяли на себя. На это были ориентированы входившие в состав хозяйства Новины коровник, пасека, фруктовый сад, находившиеся под управлением многолетних сотрудников Янковских, часть которых перебралась в Корею из Сидеми. Богатая охота обеспечивала хозяйство различными видами мяса. Другие виды продуктов, в частности, рис, муку, овощи, морепродукты Янковские закупали по баснословно низким ценам, о чём пишут практически все авторы воспоминаний, у местных корейцев, отношения с которыми были самыми добрыми [13, с. 355].

Все Янковские и особенно представители молодого поколения семьи изъяснялись на корейском и японском языках (молодежь говорила свободно), быстро освоили некоторые местные традиции и относились к местным жителям без каких-либо предубеждений. По воспоминаниям М.М. Гинце, одной из поразивших его черт Янковских было их «отношение к корейцам как к совершенно своим»: «Трудно это объяснить, но молодые Янковские были одновременно корейцами и русскими и не имели ни малейшего понятия о расовой исключительности, ни тем более, превосходстве» [4, с. 443]. Главная причина «толерантности» Янковских заключалась в том, что они были воспитаны в зоне фронтира (порубежья), специфические социальные условия которого, порожденные смешением разнокультурных обычаев и нравов без жесткой ориентации на нормативную национально-культурную модель, вели к формированию мультикультурной идентичности [15, s. 63-84]. Это, в свою очередь, способствовало достаточно высокому уровню интеграции Янковских в местное общество. В частности, на время летнего курортного сезона Янковские нанимали несколько корейцев наряду с несколькими русскими в качестве обслуживающего персонала, обеспечивая их семьям дополнительный заработок [6, с. 69; 13, с. 329]. В среде корейцев, занимавшихся охотничьим промыслом, Янковские пользовались большим уважением и поддержкой.

Снабжение дачников Лукоморья осуществлялось из Новины. Валерий и Арсений доставляли продукты и всё необходимое на одном из двух автомобилей, которые имелись в хозяйстве Янковских, используя каждую поездку, чтобы на время ускользнуть из-под контроля отца и поразвлечься в компании дачной молодёжи [13, с. 328].

Культурно-досуговая сфера курортной жизни также обеспечивалась преимущественно Янковскими и включала в себя театральные постановки, концерты и танцы, спортивные игры и горные походы. Лечебные процедуры не включались в перечень услуг, что, вероятно, лимитировалось местными властями. Ещё во время обустройства Янковских в Новине им было запрещено бурить скважины с термальными водами, чтобы не создавать конкуренции японским владельцам лечебных курортов в поселке Омпо [4, с. 434]. Не имели Янковские в своем хозяйстве и банного комплекса. По воспоминаниям дачников, они пользовались услугами японских бань в Омпо [4, с. 434, 435; 6, c. 70]. Однако эти недостатки окупались возможностью использовать 
дары богатой корейской природы - природные горячие источники в окрестностях Новины, целебный горный и морской воздух, морские ванны.

Главная роль в организации культурно-досуговой сферы курортов принадлежала жене Юрия Михайловича - Маргарите Михайловне (в девичестве Шевелёвой), которую дети и многие знавшие ее люди называли «душой семьи» [4, с. 427; 6, с. 69]. Маргарита Михайловна обеспечивала досуг и развлечения в Новине, а Лукоморье было отдано под управление её младшей дочери - Виктории, охотницы и поэтессы, имевшей в Лукоморье свое бунгало. Усилиями Маргариты Михайловны и ее невестки Натальи Николаевны, жены Павла Янковского, в Новине был организован домашний театр, участие в постановках которого принимали как члены семьи Янковских, так и отдыхающие.

Маргарита Михайловна «заболела» театром ещё в детстве, когда, приезжая из Владивостока в родную для её богатой купеческой семьи Шевелёвых Кяхту, посещала здесь любительские спектакли, постоянными участниками которых являлись их родственники Корнаковы. Впоследствии уже в Сидеми Янковская организовала семейный театр и написала для него несколько пьес. Именно на сцене этого импровизированного театра сделала свои первые актёрские шаги двоюродная сестра Маргариты Михайловны - Екатерина Корнакова, в будущем одна из ведущих актрис МХАТа $[12$, с. 14,17$]$. Выйдя замуж за Бориса Бринера, Корнакова покинула в 1931 г. с мужем Советский Союз и обосновалась в 1932 г. в Харбине. Как уже отмечалось, Бринеры имели свои дачи в Новине и Лукоморье, и Екатерина Ивановна была частой гостьей Янковских, активно участвуя в «театральной жизни» курорта. Это обстоятельство создало своеобразную "рекламу» поместьям Янковских и на курорт потянулись представители театрального и литературного мира русского Китая - В.И. Томский, Л.А. Далевич, В.В. Панова, М.В. Щербаков, Л.Н. Андерсен, Светланова, Мальцева, и др. Как вспоминала Виктория Янковская, однажды в Новину съехались сразу пять режиссёров, которые желали ставить в театре Маргариты Михайловны свои спектакли [12, с. 156]. В разгар летнего сезона спектакли ставились почти каждую субботу [4, с. 444].

Наиболее популярными видами спорта на курортах Янковских являлись теннис, волейбол и городки. Были устроены теннисные корты и волейбольные площадки [12, с. 157]. На время сезона в Новине и Лукоморье формировались по одной сборной мужской команде по волейболу, которые в конце сезона боролись за призовой кубок, и «страсти здесь разгорались не на шутку». Команда Новины была представлена хозяевами и приезжими, а в команде Лукоморья играли служащий Янковских В. Н. Вальков и владельцы местных дач. Также существовали смешанные женско-мужские команды, одну из которых возглавляла Агния (Гутя) Рокотова, жена редактора «Рубежа» М.С. Рокотова-Бибинова [4, с. 430, 431].

Взрослых отдыхающих неизменно привлекали походы к истокам реки Омпо, на Мертвое Озеро, на становой хребет Лысые Горы с красивейшим водопадом Три Чаши. Обычно поход в горы занимал несколько дней, требовал особой подготовки и разбивки базового лагеря в районе Второй Чаши [13, с. 345-349]. Восхитительные горные пейзажи Кореи никого не оставляли равнодушными. Для детей 
обычно организовывались пешие прогулки в окрестностях Новины. Другими детскими развлечениями были посещение оленьей фермы и коровника Янковских, купание, катание на больших качелях-каруселях («гигантские шаги») [4, с. 423].

Вечерами для отдыхающих устраивались концерты и танцы, пользовавшиеся большой популярностью. Проводились выборы «мисс Новина». Те, кто предпочитал более узкий круг общения, собирались у кого-либо на даче: беседовали, иногда спорили по тем или иным злободневным политическим вопросам, читали стихи, пели песни или играли в карты. Виктория Янковская нередко устраивала в Лукоморье вечерние посиделки с играми на берегу моря вокруг большого костра [4, с. $423-425,432 ; 13$, с. 329,345$]$.

Курорт Янковских мог удовлетворить и религиозные запросы отдыхающих, что было немаловажным особенно в том случае, когда некоторые семьи (главным образом женщины и дети) проводили в Корее по нескольку месяцев. В первой половине 1930-х гг. Янковские собственными руками построили из речного камня церковь-часовню, располагавшуюся недалеко от основных жилищ на горке в сосновом лесу. Служил в церкви перебравшийся с женой из Харбина и постоянно проживавший в Новине о. Иоанн Тростянский. Службы осуществлялись по субботам и воскресениям, а также во время престольных праздников, нередко сопровождаясь крестным ходом и освящением вод реки Омпо [4, с. 425; 13, с. 338,386$]$. Неоднократно посещавшая усадьбу Янковских поэтесса и танцовщица Ларисса Андерсен позднее так вспоминала крестный ход в Новине: «Это какое-то средневековое зрелище. Маленькая горстка христиан в сердце огромных языческих гор» $[1]$.

Летний курортный сезон в Новине и Лукоморье обычно длился с мая по сентябрь, но некоторые владельцы дач проводили здесь и зимние месяцы, как, например, давний друг семьи Янковских коммерсант из Шанхая Евгений Эллерс [13, с. 371]. В зимний период владельцы Новины организовывали охоту для состоятельных людей, среди которых было немало иностранцев, привлечённых «разрекламированной» периодической печатью славой Янковских как искуснейших охотников ${ }^{3}$. Для удобства охотников в 1935 г. в Новине был построен специальный зимний дом в стиле богатой корейской фанзы под черепичной крышей, получивший название «Турек». Здесь располагалось до десятка помещений, в том числе столовая, кухня, контора [13, c. 369,370$]$.

Организация зимней охоты составляла важную статью доходов семейного бизнеса. Ее закат, как и закат всего курортного хозяйства, наступил с началом Тихоокеанской войны. В условиях сворачивания курортного бизнеса Янковские сосредоточили всю свою активность на оленеводстве и промысловой охоте.

\section{Выводы}

Организация успешного курортного бизнеса семьей Янковских в Корее является одним из редких примеров активности русских эмигрантов Дальнего Востока в данной сфере. Причины успешности Янковских, по нашему мнению, нужно искать прежде всего в клановой организации хозяйства, сформированной в условиях дальневосточного фронтира и неразвитости его экономической инфраструктуры
${ }^{3}$ Статьи об охотничьих успехах Янковских неоднократно выходили в русской эмигрантской прессе Китая, в частности, в журнале «Рубеж», а также в корейской периодике (Чосон ильбо). Кроме того, Янковские упоминались в нескольких книгах, изданных в 1930-е гг. в США и Европе (S. Bergman, F.

Ossendovski). 
ещё в дореволюционный период в Приморье. Концентрация основных финансовых средств в руках главы клана, высокий уровень внутрисемейной консолидации, ранняя интеграция детей в семейную профессиональную сферу, наличие серьезных материальных ресурсов и широких интернациональных связей, помноженные на колоссальную предприимчивость и благоприятную для русских эмигрантов экономическую политику японских властей Кореи, обеспечили мощный фундамент экономического благополучия Янковских, в немалой степени зиждившегося на курортном хозяйстве Новины и Лукоморья.

Особенности функционирования курортного хозяйства Янковских были обусловлены его комплексным характером - сочетанием пляжного и прогулочно-спортивного отдыха в летний период и охотничьего сафари в зимний. Несмотря на присутствие в Новине и Лукоморье многочисленных русских отдыхающих из крупных эмигрантских центров Китая и Кореи, японцев и других иностранцев, курорты Янковских так и не приобрели по-настоящему общественный характер, оставаясь преимущественно местом отдыха для родственников, друзей и знакомых хозяев курортов. В то же время наличие в ряде регионов Китая крупных русских эмигрантских сообществ, члены которых являлись главными потребителями предоставлявшихся Янковскими курортных услуг, обеспечивало высокий уровень конкурентоспособности семейного предприятия, существовавшего по соседству с многочисленными японскими курортами. Курорты Янковских играли определенную роль и в развитии экономики региона, втягивая в свою орбиту представителей местного корейского населения. Кроме того, Новина и Лукоморье в известной степени являлись в 1930-е гг. важным культурным явлением в жизни дальневосточной эмиграции, будучи объектом притяжения деятелей русской культуры из Харбина и Шанхая - артистов, литераторов, поэтов, музыкантов, и центром любительского театрального искусства.

В контексте изучения проблемы социальной адаптации русских эмигрантов в странах Восточной Азии успешность реализации Янковскими крупного коммерческого проекта с опорой почти исключительно на семейные ресурсы (не только финансовые и материальные, но и капитал связей, особенности организации семьи, воспитания детей и т. д.) является показателем успешности включения эмигранта в чужую, в чем-то даже чуждую, среду с достаточно высоким уровнем интеграции в местное общество.

\section{Литература}

1. Андерсон Л. Одна на мосту: Стихотворения. Воспоминания. Письма. URL: https://booksonline.com.ua/view. php?book=170947 (дата обращения: 22.06.2021).

2. Бергер П., Лукман Т. Социальное конструирование реальности: Трактат по социологии знания. М.: Academia-Центр, Медиум, 1995. 323 с.

3. Бриннер Р. Империя и одиссея. Бриннеры в Дальневосточной России и за ее пределами. Фантом Пресс, 2015. 366 с.

4. Гинце М.М. Новина и Лукоморье, поместья семьи Янковских в Корее (воспоминания юного дачника) // Российское корееведение: Альманах. Вып. 5. М.: ИСАА МГУ; ИВ РАН, 2007. С. 420-448.

5. Иванов-Ардашев В.В. Злой рок чужбины. Очерки былого лихолетья: статьи, письма, интервью. Хабаровск: Хабар. краевой музей им. Н.И. Гродекова, 2008. 59 с.

6. Ильина-Лаиль О. Восточная ветвь. 
СПб.: Звезда, 2003. 288 с.

7. Капран И.К. Повседневная жизнь русского населения Харбина (конец XIX в. - 50-е гг. XX в.). Владивосток: Изд-во ДВФУ, 2011. 204 с.

8. Симбирцева Т.М. Семья Янковских в истории Приморья и русско-корейских отношений // Российское корееведение: Альманах. Вып. 5. М.: ИСАА МГУ; ИВ $\mathrm{PAH}, 2007$. C. 407-412.

9. Старосельская Н.Д. Повседневная жизнь «Русского Китая». М.: Молодая гвардия, 2006. 373 с.

10. Хисамутдинов А.А. Русские волны на Пацифике: Из России через Китай, Корею и Японию в Новый Свет. Пекин; Владивосток: Рубеж, 2013. 640 с.

11. Шаронова В. Г. История русской эмиграции в Восточном Китае в первой половине XX века. М.; СПб., 2015. 512 с.

12. Шорохи прошлого. Дневники, пись- ма и раннее литературное творчество семьи Янковских, 1907-1954 / Маргарита, Муза, Виктория Янковские: сост., вступ. ст., коммент. Е.Н. Сергеевой. Владивосток: Рубеж, 2017. 631 с.

13. Янковский В.Ю. От Сидеми до Новины. Дальневосточная сага. Владивосток: Рубеж, 2017. 608 с.

14. Clark D.N. Vanished Exiles: The Prewar Russian Community in Korea // Korean Studies: New Pacific Currents. - Honolulu: Center for Korean Studies, University of Hawaii, 1994. P. 41-55.

15. Hoerder D. Migration Research in Global Perspective: Recent Development // Sozial. Geschichte Online. 2012. N 9. S. 63-84. URL: http://www.stiftung-sozialgeschichte.de (дата обращения: 05.07.2021).

16. Simbirtseva T. In Memory of Valery Yankovsky // Acta Koreana. 2010. Vol. 13. N 1. P. 203-207.

\title{
Sergei V. SMIRNOV,
}

Doctor of History, Professor, Department of Modern and Contemporary History, Ural Federal University (Yekaterinburg, Russia).

E-mail: s.v.smirnov@urfu.ru

\section{Russian Resorts in Korea in the Late 1920s - early 1940s. (on the Example of the Activities of the Yankovsky Family)}

\author{
UDC $325.2+929.52 \quad$ DOI https://doi.org/10.24866/2542-1611/2021-3/74-84
}

The article focuses on a unique example of the successful Russian emigration, development of a large Russian resort in Korea in the conditions Yankovsky, of emigration. The research is based on documents of personal Korea, origin. The main reasons for the economic success of the Yankovskys were the clan nature of the organization of their economy, the frontier consciousness of family members, which facilitated the process of social adaptation, and the presence of a resort economy, stable socio-economic context, which was provided by the policy frontier, of the Japanese colonial authorities in Korea. In the 1930s, the amateur theater Yankovsky resort, remaining mainly a vacation spot for their relatives and friends, was an important phenomenon of the Far Eastern Russian emigration's cultural life. The termination of the functioning of the resorts was due not so much to internal as to external factors: the aggravation of the military-political situation in the region and the beginning of the Pacific War. 
For citation: Smirnov S. V. Russian resorts in Korea in the late 1920s - early 1940s. (on the example of the activities of the Yankovsky family) // Oriental Institute Journal. 2021. № 3. P. 74-84. DOI https://doi.org/10.24866/2542$1611 / 2021-3 / 74-84$

\section{References}

1. Anderson L. Odna na mostu: Stikhotvoreniya. Vospominaniya. Pis'ma. URL: $\quad$ https://booksonline.com.ua/view. php?book=170947 (data obrashheniya: 22.06.2021).

2. Berger P., Lukman T. Sotsial'noe konstruirovanie real'nosti: Traktat po sotsiologii znaniya. M.: Academia-TSentr, Medium, 1995. 323 s.

3. Brinner R. Imperiya $i$ odisseya. Brinnery v Dal'nevostochnoj Rossii i za ee predelami. Fantom Press, 2015. 366 s.

4. Gintse M.M. Novina i Lukomor'e, pomest'ya sem'i YAnkovskikh $\mathrm{v}$ Koree (vospominaniya yunogo dachnika) // Rossijskoe koreevedenie: Al'manakh. Vyp. 5. M.: ISAA MGU; IV RAN, 2007. S. 420-448.

5. Ivanov-Ardashev V.V. Zloj rok chuzhbiny. Ocherki bylogo likholet'ya: stat'i, pis'ma, interv'yu. KHabarovsk: KHabar. kraevoj muzej im. N.I. Grodekova, 2008. 59 s.

6. Il'ina-Lail' O. Vostochnaya vetv'. SPb.: Zvezda, 2003. 288 s.

7. Kapran I.K. Povsednevnaya zhizn' russkogo naseleniya KHarbina (konets XIX v. - 50-e gg. XX v.). Vladivostok: Izd-vo DVFU, 2011. 204 s.

8. Simbirtseva T.M. Sem'ya YAnkovskikh $\mathrm{v}$ istorii Primor'ya i russko-korejskikh otnoshenij // Rossijskoe koreevedenie: Al'manakh. Vyp. 5. M.: ISAA MGU; IV RAN, 2007. S. 407-412.
9. Starosel'skaya N.D. Povsednevnaya zhizn' «Russkogo Kitaya». M.: Molodaya gvardiya, 2006. $373 \mathrm{~s}$.

10. KHisamutdinov A.A. Russkie volny na Patsifike: Iz Rossii cherez Kitaj, Koreyu i YAponiyu v Novyj Svet. Pekin; Vladivostok: Rubezh, 2013.640 s.

11. SHaronova V. G. Istoriya russkoj ehmigratsii $\mathrm{v}$ Vostochnom Kitae $\mathrm{v}$ pervoj polovine XX veka. M.; SPb., 2015. 512 s.

12. SHorokhi proshlogo. Dnevniki, pis'ma i rannee literaturnoe tvorchestvo sem'i YAnkovskikh, 1907-1954 / Margarita, Muza, Viktoriya YAnkovskie: sost., vstup. st., komment. E.N. Sergeevoj. Vladivostok: Rubezh, 2017.631 s.

13. YAnkovskij V.YU. Ot Sidemi do Noviny. Dal'nevostochnaya saga. Vladivostok: Rubezh, 2017. 608 s.

14. Clark D.N. Vanished Exiles: The Prewar Russian Community in Korea // Korean Studies: New Pacific Currents. - Honolulu: Center for Korean Studies, University of Hawaii, 1994. P. 41-55.

15. Hoerder D. Migration Research in Global Perspective: Recent Development // Sozial. Geschichte Online. 2012. N 9. S. 63-84. URL: http://www.stiftung-sozialgeschichte.de (data obrashheniya: 05.07.2021).

16. Simbirtseva T. In Memory of Valery Yankovsky // Acta Koreana. 2010. Vol. 13. N 1. P. 203-207. 